\title{
DAMPAK POSITIF HARI KAUM MUDA SEDUNIA DAN FAKTOR-FAKTOR YANG MENYEBABKAN DAMPAK POSITIF ITU
}

(bagian kedua dari dua tulisan)

$$
\text { Gontí Simanullang* }
$$

\section{Pendahuluan}

Bagia kedua tulisan ini meliputi dampak positif Hari Kaum Muda Sedunia (HKMS) dan faktor-faktor yang menyebabkan dampak positif itu. HMKS memberi dampak baik kepada peserta maupun bukan peserta. Kesaksian peserta mengenai dampak itu meliputi makna eksperiensial kekatolikan, host families yang ramah, pengalaman iman, pengalaman akan persaudaraan dan kebersamaan. Dampak positif lainnya adalah keraguan menjadi kepastian, dan evaluasi positif dari komunitas Yahudi. Sedangkan faktor-faktor yang menimbulkan dampak positif itu adalah pemimpin Gereja, host families, prosesi dengan salib dan ikon Bunda Maria, anthem, katekese, sakramen rekonsiliasi, dan adorasi Sakramen Mahakudus.

\section{Dampak Positif Hari Kaum Muda Sedunia}

\section{Kekatolikan Dimaknai Secara Eksperiensial}

Di antara sekian banyak dampak HKMS, salah satu dampak positif dan signifikan bagi peserta adalah makna kekatolikan. Bagi peserta, kekatolikan itu bukan pertama-tama ideologis, melainkan realita. HKMS mengantar peserta kepada makna esperiensial kekatolikan. Di bawah ini disajikan kesaksian peserta mengenai hal itu.

HKMS adalah festival kaum muda yang sarat makna. Di sana terungkap secara konkret makna universalitas atau kekatolikan Gereja yang dipimpin oleh seorang gembala tertinggi, Paus. Kata Katolik menunjuk pada universalitas Gereja. HKMS adalah perjumpaan kaum muda dari seluruh dunia dalam satu iman, dan karena itu menjadi kesaksian iman kepada dunia. HKMS adalah ekspresi bahwa kita keluarga besar Katolik dipersatukan dalam satu baptisan. Dalam pertemuan itu kita mendengar Paus yang mengajar dengan penuh wibawa dan karisma. HKMS adalah 
represetansi konkret apa artinya satu kawanan yang Katolik di bawah satu gembala. ${ }^{1}$

HKMS adalah pertemuan kaum muda dari segala suku, bahasa dan bangsa yang berkumpul di sekeliling Yesus Kristus yang berbicara kepada mereka. HKMS itu jelas mengatakan kepada dunia apa itu arti Katolik. Tidakkah hal yang menakjubkan bahwa kaum muda Katolik dari seluruh dunia bisa menunjukkan apa artinya persaudaraan yang Katolik dengan iman yang berakar dan dibangun dalam Kristus?2

Menghadiri HKMS adalah kesempatan untuk memberi kesaksian tentang universalitas Gereja yang sejati. Selain itu, kita bisa bertemu secara langsung dengan Paus yang menyalurkan kasih dan karunia Allah kepada kita. ${ }^{3}$

HKMS adalah media pengungkapan iman yang satu dan Katolik dalam konteks budaya bangsa tertentu. HKMS juga merupakan kesempatan untuk merenovasi Gereja lokal yang adalah Katolik.

HKMS adalah pengalaman pentakostal, suatu peziarahan yang Katolik dalam Gereja Katolik, di mana seseorang secara langsung bisa mengalami kekatolikannya, yakni bahwa ia selaku Katolik adalah bagian integral dari keseluruhan Gereja Katolik. HKMS menyatakan kepada kita bahwa Yesus Kristus tetap hidup, aktif, berkarya di dalam hati orang-orang muda.

${ }^{1}$ Rachel Howell [Lihat http://www.ncregister.com/daily-news/4reasons-to-go-to-world-youth-day/, 23 agustus 2012.]

${ }^{2}$ Martha Fernandez-Sardina adalah direktur evangelisasi Keuskupan Agung Santo Antonius. seorang pembicara bilingual nasional dan pelatih, konsultan kementerian dan penerjemah. Dia pemandu acara TV mingguan, sering menjadi tamu di acara radio, penulis kolom surat kabar, blog berkala www.archsa.org/Evangelisasi,iEvangelize.wordpress.com)

[Lihat http://www.satodayscatholic.com/ Martha_090911.aspx, 23 Agustus 2012.]

${ }^{3}$ Laurie Ghigliotti writes from Atchison, Kansas [Lihat http://www.ncregister.com/daily-news/world-youth-day-here-weare\#ixzz24Llf7XtW, 23 Agustus 2012.] 
Gonti Simanullang, Dampak Positif Hari Kaum Muda Sedunia

HKMS mengingatkan kita bahwa Gereja tidak menjadi tua sampai akhir zaman, sebaliknya malahan semakin muda setiap tahun. ${ }^{4}$

\section{Host Families yang Ramah}

Host Families adalah keluarga-keluarga Katolik yang berdomisili di negara tempat HKMS diselenggarakan dan yang dengan sukarela menampung peserta HKMS selama beberapa hari di rumah-rumah mereka. Dalam artikel bagian pertama telah disajikan sekilas bahwa terdapat sebanyak 6.000 host families yang bersedia menampung kaum muda internasional tahun 1985 yang datang ke Roma atas undangan Paus Yohanes Paulus II. Kesaksian di bawah ini diangkat dari HKMS yang berlangsung di Madrid, Spanyol, tahun 2011.

Shirley dan Petrus bersama sepuluh peserta lainnya dari Jakarta, Indonesia, bergabung dalam kelompok yang disebut New Heart Community. Shirley menuturkan kesannya selama tinggal bersama di rumah keluarga Clemente dan Manuela selaku host family di Spanyol.

Orang tua angkat kami Clemente dan Manuela membiarkan kami menempati kamar tidur putrinya yang sudah dibuat rapi.

Setiap pagi sebelum kami berangkat untuk katekese, orang tua angkat kami bangun terlebih dahulu dan menyiapkan sarapan bagi kami semua, lengkap mulai dari toast [roti panggang], ham dan keju juga dengan juice, kopi dan teh. Selama sarapan pagi kami berbincang-bincang mengenai berbagai macam topik ringan disertai dengan pemberitahuan mengenai ramalan cuaca hari bersangkutan sehingga kami dapat mewaspadainya. Mengingat Madrid dalam musim panas, cuacanya menjadi sangat ekstrim karena panas udaranya bisa mencapai suhu $40^{\circ}$ Celcius. Begitulah keramahan di pagi hari yang kami alami bersama orang tua angkat kami.

Lain pagi hari, lain malam hari. Setiap hari kami baru kembali ke rumah sekitar pukul 23.00 setelah melalui rangkaian acara yang panjang dan meletihkan karena faktor cuaca yang kurang mendukung. Para orang tua angkat kami dengan sabar menanti kedatangan kami kembali dan menyiapkan snack ringan yang

${ }^{4}$ Christopher Stefanick adalah direktur Pemuda, Remaja dan Kementerian Kampus untuk Keuskupan Agung Denver serta pembicara dan penulis. Untuk informasi lebih lanjut, lihat www.chris-stefanick.com [Lihat http://www.archden.org/index.cfm/ID/6754, 23 agustus 2012.] 
dapat kami santap sebelum pergi tidur. Tidak hanya itu, mereka dengan antusias menanyakan kegiatan kami pada hari itu, apa saja yang kami alami dan kami peroleh. Cerita dan obrolan tersebut bisa berlangsung hingga tengah malam layaknya keakraban sebuah keluarga yang sudah terjalin lama.

Tentu saja selama tinggal bersama mereka kami merasakan seperti bagian dari mereka, layaknya seorang anak yang masih dibimbing dan dilayani. Mereka pun dengan senang hati menolong kami mulai dari hal-hal sederhana seperti memberi petunjuk arah dan transportasi menuju suatu tempat hingga membantu mencucikan pakaian-pakaian kotor kami. Luar biasa apa yang mereka lakukan dengan tulus bagi kami 'anakanaknya'.

Apa yang sudah kami alami selama menjadi anak angkat dan tinggal di rumah mereka akan menjadi kenangan yang tak terlupakan dan kehangatan tersebut masih kami rasakan hingga kini. Semua bentuk perhatian dan kasih sayang yang mereka tunjukan menjadi bukti hadirnya cinta Tuhan secara utuh melalui diri mereka tanpa batas sekat-sekat ras dan budaya. Apa yang sudah mereka lakukan merupakan penjelmaan dari wujud perbuatan Yesus pada kita anak-anakNya. Terima kasih Tuhan atas pengalaman yang luar biasa yang Engkau berikan kepada kami, biarlah berkat dan rahmat-Mu mengalir terus dalam keluarga para orang tua angkat kami. ${ }^{5}$

\section{Pengalaman Iman}

HKMS menorehkan pengalaman iman bagi peserta. Hal itu nyata dari kesaksian-kesaksian yang terungkap dalam pernyataanpernyataan berikut. Pernyataan-pernyataan peserta itu dipertahankan dalam bentuk pronomen pertama dan merupakan ringkasan dari apa yang telah mereka tuliskan.

Bagiku malam vigilia itu sangat berkesan. Pada saat itu, aku menerima sakramen rekonsiliasi. Sesudahnya, aku mengikuti adorasi. Peristiwa-peristiwa itu telah memberikan kekuatan baru

5http:// kamerauke.blogspot.com/2011/10/mereka-menantikedatangan-kami.html, 20 Oktober 2012. 
bagiku untuk semakin memperdalam keyakinanku akan kasih Allah. ${ }^{6}$

HKMS menjadikan orang muda saksi kuasa Allah yang selalu memberdayakan, melindungi dan membimbing kita. ${ }^{7}$

Malam vigilia HKMS memberi sejuta kisah bagiku. Aku menyaksikan pemandangan yang sangat indah, ribuan lilin bernyala yang mengitari altar dan monstran. Cahaya dan pancaran lilin-lilin itu menguatkanku untuk ikut terus berjaga. ${ }^{8}$

Aku sangat tersentuh oleh setiap peristiwa yang telah kuikuti. Aku merasakan Tuhan sungguh berkarya di dalam diriku. ${ }^{9}$

Cuaca sangat dingin selama sepekan HKMS di Sydney. Cuaca yang sangat dingin itu sifatnya situasional, di luar dugaan. Namun demikian, orang-orang muda bertahan untuk mengenal dan merasakan Allah secara lebih dekat dan lebih baik. ${ }^{10}$

Aku merasakan suka cita mendalam ketika menyaksikan aklamasi Injil yang dibawakan oleh para seminaris dari Fiji. Tanpa sadar, aku berurai air mata dan tidak dapat berkata apaapa. ${ }^{11}$

Pengalaman HKMS 2008 di Sydney sangat membantu perkembangan imanku. Sesi katekese yang diorganisir host parish menjawab apa yang selama ini menjadi pertanyaaan bagiku. ${ }^{12}$

HKMS di Madrid, Spanyol, adalah pengalaman luar biasa bagiku. Aku merasakan cinta Allah yang begitu besar padaku. Aku bisa mengalami suka cita ini bersama dengan rekan-rekan senegaraku dan orang-orang muda dari seluruh dunia. ${ }^{13}$

${ }^{6}$ http://lingayani.blogspot.com/2011/04/international-oblate-youthencounter.html, 24 Oktober 2012.

7http:// bluepanjeet.net/2008/08/01/1346/story-fijian-gospel-

acclamation-HKMS -2008-final-mass-sydney/, 23 juni 2012.

${ }^{8}$ http://www.patersondiocese.org/moreinfo.cfm?web-ID=2673,

26

Oktober 2012.

${ }^{9}$ http:// bluepanjeet.net/2008/08/01/1346/story-fijian-gospel-

acclamation-HKMS -2008-final-mass-sydney /, 23 juni 2012.

${ }^{10} \mathrm{http}$ :/ / bluepanjeet.net/2008/08/01/1346/story-fijian-gospel-

acclamation-HKMS -2008-final-mass-sydney/, 23 juni 2012; bdk, http://twitter.com/josephja-joseph-j-Anthraper.

${ }^{11}$ http:/ / bluepanjeet.net/2008/08/01/1346/story-fijian-gospelacclamation-HKMS -2008-final-mass-sydney /, 23 juni 2012.

${ }^{12}$ http:/ / lingayani.blogspot.com/2011/04/international-oblate-youthencounter.html, 24 Oktober 2012.

${ }^{13}$ http://www.HKMS tours.com/pilgrim-faqs/, 27 Oktober 2012. 
Menghadiri HKMS di Madrid, Spanyol, merupakan salah satu keputusan terbaik selama hidupku. Di sana hubunganku dengan Tuhan terasa semakin kuat dan erat. Event ini mendorongku untuk menunjukkan Kristus kepada orang lain agar mereka mampu melihat terang Kristus. ${ }^{14}$

Bagiku, HKMS adalah pengalaman yang sulit kulupakan dan kulukiskan. Suka dan duka yang kualami sungguh bermakna. Cuaca dingin, lingkungan baru, serta orang-orang yang kujumpai membuatku sanggup berkata bahwa Tuhan ada di mana-mana. ${ }^{15}$

Dampak positif HKMS dalam hal pengalaman iman bukan hanya berlaku bagi peserta, melainkan juga bagi non-peserta yang mengikuti HKMS melalui media massa. Pernyataan-pernyataan signifikan di bawah ini membuktikan dampak HKMS terhadap iman mereka.

Aku mengikuti HKMS melalui media elektronik/internet/website. Aku menyimak setiap liputan yang disiarkan melalui televisi atau dimuat di internet. Salah satu liputan yang paling kuminati ialah prosesi dan pembacaan Sabda Allah dan aklamasi Injil pada perayaan puncak HKMS di Sydney. Aku terharu dan bangga sebagai orang muda Katolik. Aku bersyukur kepada Tuhan karena Dia telah membangkitkan jiwaku. Aku pun menulis agar kaum muda yang ada di seluruh dunia diberkati dan tetap bertumpu pada Sabda Allah. ${ }^{16}$

$\mathrm{Aku}$ meneteskan air mata ketika mendengar anak-anakku berceritera tentang pengalaman mereka di HKMS, khususnya Ekaristi misa bersama dengan Sri Paus. Aku yakin hanya Tuhan yang pantas disembah dan dipuji. Dialah satu-satunya Allah yang benar. Aku bersyukur sekali, karena telah kucoba memberikan kasih karunia kepada ketiga anakku, sehingga mereka dibantu untuk mengalami kasih Allah. ${ }^{17}$

${ }^{14}$ http://www.HKMS tours.com/pilgrim-faqs/, 27 Oktober 2012.

${ }_{15}$ Yulius Malli, http://keuskupan.blogspot.com/2008/2009/worldyouth-day-2008-we-have-received.html, 23 Oktober 2012.

${ }^{16}$ http:/ / bluepanjeet.net/2008/08/01/1346/story-fijian-gospelacclamation-HKMS -2008-final-mass-sydney /, 23 juni 2012.

${ }^{17} \mathrm{http}: / /$ www.catholicherald.co.uk/commentandblogs/2011/08/24/wor

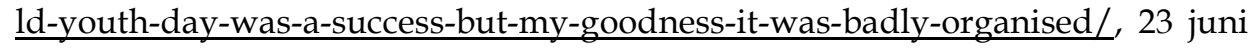
2012. 
Gonti Simanullang, Dampak Positif Hari Kaum Muda Sedunia

Aku begitu terkesan dengan seluruh kegiatan HKMS di Sydney. Allah kita adalah Allah yang mengagumkan. Dia sungguh luar biasa dan melampaui akal budi manusia. Semoga kaum muda Katolik mampu membuktikan kepada dunia bahwa kita memiliki iman yang mengagumkan. ${ }^{18}$

Aku mengalami sentuhan Allah dan mengalami kegembiraan yang tiada taranya, meskipun hanya menyaksikan lewat televisi. Aku berharap suatu saat bisa menjadi salah seorang peziarah HKMS. Bagiku, HKMS adalah perayaan iman. ${ }^{19}$

4. Semangat Persaudaraan, Kebersamaan dan Kekeluargaan

Dimensi persaudaraan, kebersamaan dan kekeluargaan merupakan faktor-faktor positif lain yang diperoleh peserta dari HKMS. Kutipan di bawah ini merupakan kesaksian peserta.

Menurutku, penderitaan dan kegembiraan kami hadapi bersama. Everyday I miss them a lot! And I really received the power from Him. Aku memperoleh banyak teman dari seluruh dunia yang sampai sekarang masih keep in touch. Aku berharap bisa menjadi volunteer pada HKMS 2011 di Madrid, Spanyol..20

Bagiku, kendatipun di zaman sekarang ini sulit menemukan orang-orang muda di dalam gereja, namun HKMS adalah momen tepat untuk menghabiskan waktu bersama dengan orang muda yang datang dari seluruh dunia untuk bertemu dengan Paus, terlebih dengan Yesus Kristus. Pengalaman HKMS memberikan kekuatan bagiku untuk membantu orang-orang muda menyadari betapa Tuhan mengasihi kaum muda. ${ }^{21}$

Aku sangat terkesan dengan kebersamaan yang terjalin di antara kaum muda dari negara-negara lain pada HKMS 2005 di Koln, Jerman. Kami hanya memikirkan saat-saat di mana kami bercakap-cakap, bergembira bersama, berbagi pengalaman, dan

\footnotetext{
${ }^{18 h t t p: / / ~ b l u e p a n j e e t . n e t / 2008 / 08 / 01 / 1346 / s t o r y-f i j i a n-g o s p e l-~}$ acclamation-HKMS -2008-final-mass-sydney/, 23 juni 2012.

${ }^{19}$ http:// bluepanjeet.net/2008/08/01/1346/story-fijian-gospelacclamation-HKMS -2008-final-mass-sydney /, 23 Juni 2012.

${ }^{20} Y$ ulius Mali, http:// keuskupan.blogspot.com/2008/2009/world-youthday-2008-we-have-received.html, 23 Oktober 2012. Veronika Wijaya, Mamuju.

${ }^{21}$ Julian Dos Santos dan Chris Sheri, http://www.cny.org/stories/Young-Pilgrims-From-New-York-Are-Ready-forWorld-Youth-Day,5926, 11 Juli 2012. Darwin Torres
} 
melupakan segala unsur politik, bahasa, dan perbedaan di antara kami. Kami yakin bahwa kami semua dapat merasa seperti ini, karena kami memiliki cinta kasih di dalam hati kami. Ini merupakan kesempatan bagi kami untuk melihat dan merasa dekat secara langsung dengan gembala kami di dunia, yaitu Bapa Suci Benediktus.22

Pengalaman yang cukup berkesan ialah saat sesi diskusi kelompok. Dalam diskusi tersebut aku mendapat gambaran bagaimana orang-orang muda di luar Pulau Jawa harus survive menantang alam demi terwujudnya sebuah komunitas yang solid. Pelajaran berharga yang tidak kalah penting ialah mengerti dan menerima setiap orang yang karakternya berbeda. ${ }^{23}$

Aku kagum melihat antusiasme peserta HKMS. Aku bersama dengan 200.000 orang muda dan remaja lainnya merasakan kebersamaan. Pengalaman bersama tersebut menandakan bahwa Kristus sungguh hadir bersama dengan kami. Aku hampir tidak percaya ketika bisa melihat Paus secara langsung. ${ }^{24}$

HKMS telah menjadi momen berharga bagiku untuk berinteraksi dengan orang-orang dari seluruh dunia, bertemu dengan umat Katolik dari segala penjuru dunia. ${ }^{25}$

Bagiku HKMS adalah pertemuan damai terbesar antar kaum muda dalam sejarah. HKMS telah menjadi saksi indah bagi perdamaian dan kehidupan bersama Kristus. ${ }^{26}$

HKMS adalah pengalaman menakjubkan yang mengubah hidup dan membawa sukacita dan iman. Di sana kegembiraan dan antusiasme kaum muda tampak bercahaya. Mereka berdoa bersama, berbagi iman dan saling memberi inspirasi. Persahabatan yang terjalin menandakan suatu motivasi untuk

${ }^{22}$ http://www.st-yohanesbosco.org/bosconian-

detail.php?id=476\&sub_id=154, 21 Agustus 2012.

${ }^{23}$ http:// lingayani.blogspot.com/2011/04/international-oblate-youthencounter.html, 24 Oktober 2012. Linggayani Soetoro, Indonesia.

${ }^{24} \mathrm{http}$ ///www.patersondiocese.org/moreinfo.cfm?web-ID=2673, 26

Oktober 2012. Ignascio Angulo-Pizarro, Mountain Lakes.

${ }^{25} \mathrm{http}: / /$ my.hsj.org/schools/Newspaper/tabid/100/view/frontpage/sc hoolid/2888/articleid/445987/Newspaperid/2966/Delegates_Prepare_For_Wo rld_Youth_Day_Conference_in_Madrid.aspx, 30 Agustus 2012. Katie Daniels.

${ }^{26}$ http://HKMS central.org/category/reflections, 17 September 2012. Sr. Susan. 
semakin mendalam terlibat di dalam kehidupan gerejawi. ${ }^{27}$ Meskipun terik matahari begitu panas, badai petir menggelegar dan malam yang lembab, namun para peziarah tidak berhenti bernyanyi dan membunyikan gendang untuk memuji Tuhan. Para peziarah siap menjadi pewarta Injil dalam semua bahasa. Solidaritas dan kegembiraan di dalam diri orang muda benarbenar indah dan memukau. ${ }^{28}$

\section{Panggilan Religius}

Keinginan menjadi imam atau suster mulai tertanam dalam diri orang muda sesudah menghadiri HKMS. Dampak positif ini merupakan riffle effect (dampak positif lanjutan) dari HKMS. Kesaksian ini tidak secara langsung diungkapkan peserta, melainkan melalui kesaksian orang lain. Center for Applied Research in the Apostolate (CARA) - Pusat Penelitian Aplikatif dalam Kerasulan - yang ada di Amerika Serikat, menulis bahwa keinginan orang muda untuk menjadi imam atau suster empat kali lebih besar sesudah mengikuti HKMS. Dari segi kuantitatif, Uskup Agung Milwaukee, Timothy Dolan, ${ }^{29}$ menyatakan bahwa 50\% laki-laki merasa diteguhkan dan ingin menjadi imam setelah mengikuti HKMS 2005 di Cologne, Jerman. ${ }^{30}$ Observasi ini didukung oleh Suster John Paul. Dia mengatakan bahwa di biara Suster-suster Maria Bunda Ekaristi, Kanada, "empat orang gadis memutuskan masuk biara sesudah mengikuti HKMS di Denver. Hampir setiap panggilan imam dan membiara di Kanada tidak terlepas dari sosok Paus Yohanes Paulus II, penggagas HKMS yang selalu menghadirinya." 31

Uskup Agung Joseph W. Tobin bersikap skeptis terhadap pendapat yang mengatakan bahwa HKMS merupakan persemaian panggilan hidup religius. Tetapi, suatu studi membenarkan bahwa sebagian besar pria dan wanita muda yang memasuki hidup religius

\footnotetext{
${ }^{27 R e v . ~ F r . ~ M a r o u n ~ E l ~ K a z z i, ~ “ c o m e ~ t o ~ r i o ~ 2013 ” . ~}$

http://www.HKMS tours.com/HKMS -pilgrimages/nationalgroup/maronites/, 23 januari 2013.

${ }^{28}$ http://HKMS central.org/category/reflections, 17 September 2012.

${ }^{29}$ Timothy Dolan adalah rektor sebuah perguruan tinggi di Roma. [Lihat http://www.ncregister.com/daily-news/cara-study-finds-abundance-ofpotential-priests-and-sisters/, 20 Oktober 2012.]

${ }^{30}$ Tim Drake, http://www.ncregister.com/daily-news/cara-study-findsabundance-of-potential-priests-and-sisters/, 20 Oktober 2012.

${ }^{31}$ Terry Th Ponomban, In Loving Memory of John Paul II (Yogyakarta: Yayasan Pustaka Nusantama, 2005), hlm.33.
} 
menyatakan bahwa HKMS memberikan konstribusi signifikan dalam menyuburkan panggilan religius. 32

\section{Keraguan Menjadi Kepastian}

Sebelum HKMS dilangsungkan, tidak setiap orang yakin akan antusiasme kaum muda terhadap invitasi Paus. Keraguan itu bukan hanya berasal dari awam, tetapi juga dari uskup-uskup. Uskup-uskup Amerika Serikat tidak yakin bahwa HKMS 1993 di Denver, Amerika Serikat, akan berhasil. Keragauan mereka bukan tanpa alasan. Mereka melihat bahwa sekularisme di Amerika Serikat dan Perancis berpengaruh kuat terhadap antusiasme kaum muda untuk menghadiri HKMS.

Media masa terkemuka di Amerika Serikat memprediksi bahwa HKMS di Denver akan mengalami kegagalan total. Para uskup pun pesimis dan membenarkan prediksi itu. Mereka memperkirakan bahwa adalah luar biasa bila terdapat 200.000 anak muda yang menghadiri HKMS di Denver. Ternyata, dugaan ini keliru sebab ternyata ada sebanyak 700.000 orang muda datang memenuhi undangan Paus Yohanes Paulus II. 33

Keraguan yang sama timbul juga di hati para uskup Perancis ketika didaulut menjadi penyelenggara HKMS 1997 di Paris, Perancis. Keraguan ini muncul juga di kalangan uskup-uskup di Roma, Italia. Tetapi dengan secercah keyakinan, Kardinal Lustiger, yang menjadi Uskup Agung Paris, memberanikan diri. Beliau mengarahkan segala kemampuannya untuk mensukseskan pertemuan akbar ini. Ternyata keraguan itu sirna melihat antusiasme kaum muda dalam HKMS di Paris.

Keraguan para uskup Amerika Serikat dan Perancis terhadap HKMS berubah menjadi kepastian sesudah HKMS terselenggara di dua negara sekularis itu. Dengan keberhasilan ini, umat Katolik mulai berbicara dengan harapan teguh bahwa musim semi baru telah muncul dalam Gereja Katolik, khususnya Gereja Katolik di Amerika Serikat dan Perancis. $^{34}$

${ }^{32}$ Cindy Wooden, "WYD and Vocations: Youth Want to Be Heard, http://www.catholicnews.com/data/stories/cns/1103210.htm, 11 Juli 2012.]

${ }^{33}$ Stanislaw Dziwisz, Lebih Jauh bersama Karol ..., hlm. 204-206.

${ }^{34}$ Stanislaw Dziwisz, Lebih Jauh bersama Karol ..., hlm. 204-206. 
7. Apresiasi dari Komunitas Yahudi

Daud Hatcwell 35 memberikan dukungannya terhadap kegiatan HKMS dan mengevaluasi penyelenggaraan HKMS di Madrid dengan "absolute success" (keberhasilan luar biasa). Ia mengatakan,

Kita yang memikirkan hal-hal yang sama mesti juga bersamasama. Dengan HKMS ini kaum muda merasa dihargai dan diperhatikan. Setiap orang berhak untuk mengekspresikan diri, termasuk dalam hal keyakinan. HKMS ini dapat membangun dan mengembangkan tali keakraban di antara yang satu dengan yang lain.

HKMS adalah peristiwa sangat besar dan luar biasa, gerakan yang sangat positif di mana momen spiritual yang begitu menonjol dapat terlaksana dengan baik. Dia menyambut hangat pesan Paus Benediktus XVI tentang suatu nilai moral dan rohani dalam menghadapi relativisme etik. Baginya, pesan itu bukan saja ditujukan kepada orang-orang muda Katolik, tetapi kepada seluruh dunia. Pesan itu sifatnya universal.

Daud juga setuju dengan pesan Paus yang mengajak kaum muda untuk tidak hidup dalam kepentingan individual, tetapi lebih menitikberatkan pada nilai-nilai rohani dalam pelayanan sehari-hari. ${ }^{36}$

\section{Faktor-faktor yang Menyebabkan Dampak Positif}

Faktor-faktor yang menyebabkan dampak positif HKMS boleh disebut sebagai pokok-pokok signifikan yang mewarnai HKMS, misalnya pemimpin Gereja, host families, prosesi dengan salib dan ikon Bunda Maria, anthem, katekese, sakramen rekonsiliasi, dan adorasi Sakramen Mahakudus. Pokok-pokok signifikan ini tampaknya relevan bagi kaum muda dalam pembinaan iman mereka. Pokok-pokok inilah perlu diintegrasikan dalam pastoral kaum muda, khususnya ketika diselenggaraan pertemuan kaum muda pada tingkat paroki, keuskupan, provinsi gerejawi, ataupun nasional.

\section{Pemimpin Gereja}

HKMS tidak bisa dipisahkan dari Paus selaku pemimpin Gereja Universal. Kaum muda dalam HKMS merindukan kehadiran Paus untuk bertatap muka secara langsung dengannya, menjabat tangannya,

${ }^{35}$ Daud Hatcwell adalah Wakil Presiden dari Komunitas Yahudi di Madrid.

${ }^{36}$ Miriam Diez $i$ Bosch, A Jewish Reaction to WYD [Lihat http://www.zenit.org/article-33294?l=english, 14 juli 2012.] 
mendengar instruksi dan harapannya terhadap mereka, menyambut komuni kudus dari tangannya. ${ }^{37}$

Kehadiran Paus dalam HKMS tingkat internasional ternyata sangat berkesan dan bermakna bagi kaum muda. Kesan itu terungkap dalam beberapa pernyatan berikut:

HKMS adalah suatu kesempatan yang istimewa untuk bisa bertemu, melihat secara langsung Paus Benediktus XVI sebagai Gembala orang-orang muda.

Momen ini [HKMS] adalah saat yang tepat untuk menghabiskan waktu bersama dengan orang-orang muda yang ada di seluruh dunia dan terutama bersama dengan Bapa Suci.

Aku hampir tidak percaya ketika melihat Paus secara langsung. Pengalaman ini mengingatkan aku atas cerita ibuku, ketika ia melihat Paus Yohanes Paulus II pada HKMS. Pertemuan ini merupakan karya Roh Kudus yang senantiasa membimbing aku. Aku sangat senang ketika Paus Benediktus XVI berlalu di hadapanku.

Pertemuan kaum muda tingkat keuskupan mungkin akan lebih signifikan dan relevan bagi kaum muda apabila uskup, selaku pemimpin tertinggi keuskupan, hadir pada dua hari terakhir untuk bertemu dan berdialog dengan mereka. Perhelatan itu ditutup dengan perayaan Ekaristi yang dipimpin oleh uskup. Dengan ini, ajakan dan harapan Paus Yohanes Paulus II, agar HKMS tingkat keuskupan diselenggarakan setiap Minggu Palma menjadi relevan dan aktual. Mungkin perhelatan itu bisa diadakan selama tiga hari, dibuka pada hari Jumat dan ditutup dengan perayaanEekaristi pada hari Minggu Palma. Paroki penyelenggara berganti setiap tahun dan pada saat penutupan, uskup mengumumkan secara resmi paroki penyelenggara HKMS tingkat keuskupan berikutnya.

\section{Host Families}

Ketika Paus Yohanes Paulus II mengumumkan pertemuan kaum muda sedunia di Roma pada tahun 1984, sebanyak 6.000 host families dengan antusias menyatakan kesiapsediaan mereka untuk menampung kaum muda di rumah-rumah mereka. Sejak itu, pola ini telah menjadi bagian signifikan dalam pelaksanaan HKMS tingkat internasional. Sikap ini menunjukkan secara nyata apa artinya Katolik. Pernyataan-

37James J. Bacik, Spirituality in Transition (Kansas City: Sheed \& Ward, 1996), hlm. 76. 
pernyataan di bawah ini memberi bukti tentang efek host families bagi kaum muda dalam memaknai host families dan kekatolikan secara nyata.

Aku bangga sebagai warga Gereja Katolik yang memiliki rasa kesatuan universal yang begitu kuat.

HKMS adalah sarana untuk mengungkapkan iman Katolik sekaligus sebagai saksi iman pada dunia. Sebagai orang Katolik, kita adalah keluarga besar yang dipersatukan dalam satu baptisan.

Menghadiri HKMS adalah kesempatan untuk menyaksikan keuniversalan Gereja Katolik yang sejati.

HKMS adalah pengalaman yang luar biasa, suatu pengalaman sebagai Gereja Katolik, di mana seseorang secara langsung bisa mengalami kekatolikan.

Apa yang sudah kami alami selama menjadi anak angkat dan tinggal di rumah mereka akan menjadi kenangan yang tak terlupakan dan kehangatan tersebut masih kami rasakan hingga kini. 38

Host families juga mengalami kesan tersendiri dalam menampung kaum muda di rumah mereka. Berikut adalah salah satu ungkapan mengesankan dari host families, "Rumah kami terasa kosong tanpa kamu. Terima kasih karena kamu telah membagikan pengalaman perziarahan kamu bersama kami."

Pola di atas boleh juga dipromosikan di kalangan keluargakeluarga Katolik di paroki penyelenggara HKMS tingkat keuskupan setiap tahun. Pola lama, yakni menampung kaum muda di aula paroki dan ruangan-ruangan kelas di mana toilet dan kamar mandi kurang atau sangat tidak memadai, bisa diatasi oleh host families. Pola host families ini mungkin akan membantu kaum muda dalam memaknai kekatolikan secara nyata melalui pengalaman mereka tinggal dalam keluarga-keluarga Katolik selama pertemuan itu, sebagaimana telah dialami kaum muda dalam HKMS tingkat internasional.

3. Prosesi dengan Membawa Salib, Ikon Bunda Maria, dan Lilin Bernyala

Rumah Pembinaan Fransiskan di Nagahuta, Pematangsiantar, mengagendakan Mei Bulan Maria dan dan Oktober Bulan Rosario dengan mengadakan seminar dan perayaan Ekaristi pada pembukan dan penutupan Bulan Maria dan Bulan Rosario. Seminar berupa katekese selalu mendahului perayaan Ekaristi. Sebelum perayaan

${ }^{38}$ Cerita mengesankan yang lebih mendetil dapat dilihat pada lampiran. 
Eekaristi berlangsung, ribuan umat telah berdiri di sekitar patung Bunda Maria, sementara imam, misdinar, lektor dan pengusung patung Bunda Maria dan lampu mempersiapkan diri di salah satu ruangan. Ketika tiba waktunya untuk memulai perayaan ekaristi, 6 pengusung patung Bunda Maria, pembawa lampu bernyala, misdinar, lektor dan imam berjalan menuju lapangan tengah di mana terdapat patung Bunda Maria. Sesudah pembukaan singkat termasuk penyalaan lilin besar yang sudah dipersiapkan di depan patung Bunda Maria, lilin hadirin dinyalakan dan prosesi bergerak menuju gua Maria yang berjarak 200 meter dari tempat pembukaan. Prosesi berlangsung di mana setiap orang yang hadir memegang lilin bernyala mengikuti salib yang dibawa seseorang, dikuti misdinar lalu pengusung patung Bunda Maria, dan para imam sambil bernyanyi dan meretisir doa rosario sepanjang jalan menuju gua Maria.

Ribuan umat terlibat. Menurut observasi penulis, prosesi dengan patung Bunda Maria, lilin bernyala, lampu bernyala memberi kesan signifikan bagi umat. Agenda ini telah diselenggarakan puluhan kali dan tetap dihadiri ribuan umat. Suasana sangat indah dan mengesankan.

Prosesi salib turut juga mewarnai Indonesian Youth Day (IYD), Hari Kaum Muda Indonesia di Sanggau. Orang-orang muda memanggul salib ke keuskupan untuk diberkati dan kemudian diarak dari satu stasi ke stasi yang lain. Pengarakan salib ini bertujuan untuk menyampaikan pesan bahwa IYD akan diselenggarakan di keuskupan Sanggau yang diikuti representasi kaum muda dari 37 keuskupan di Indonesia. Terhadap pengarakan salib itu, Pastor Yance, Ketua Komisi Kepemudaan Keuskupan Agung Sanggau, mengungkapkan keterharuan dan kebanggaannya atas antusiasme umat menyambut salib IYD. 39

HKMS tidak terlepas dari prosesi dengan membawa salib dan ikon Bunda Maria sambil bernyanyi dan meretisir doa rosario. Prosesi itu terkadang diisi dengan jalan salib dengan jarak beberapa kilometer. Kaum muda terlibat dengan antusias. Hal seperti ini bisa diangkat dalam pertemuan kaum muda di paroki atau keuskupan. Prosesi Sakramen Mahakudus menuju tempat adorasi bisa dilangsungkan sebagai opsi lain dari prosesi jalan salib dengan membawa salib, ikon Bunda Maria dan lilin bernyala. Kegiatan seperti ini sangat tepat dilangsungkan pada malam hari. Intinya adalah kaum muda perlu

${ }^{39}$ Moses Thomas dan Aprianita Ganadi, "Salib Pembawa Kabar", dalam Hidup, 43/66 (21 Oktober 2012), hlm. 10-11. 
dilibatkan secara aktif dalam prosesi, misalnya dengan memegang simbol-simbol iman kekatolikan seperti disebutkan di atas.

\section{Anthem}

Hal signifikan lainnya dalam event HKMS ialah anthem. Anthem itu berbeda pada setiap HKMS. Proses pengadaan anthem itu ialah panitia penyelengara mengadakan sayembara penulisan anthem yang sesuai dengan tema pertemuan. Peserta sayembara adalah kaum muda dari negara penyelenggara HKMS bersangkutan. Pemenang sayembara itu diumumkan secara resmi dan anthem itu dikirim kepada panitia yang mengorganisir kaum muda di negara-negaranya yang akan menghadiri HKMS di negara penyelenggara untuk dilatih. Anthem itu akan sering dinyanyikan baik sebelum maupun selama HKMS, misalnya untuk membuka pertemuan kelompok, mengawali malam kesenian, serta penyambutan Paus. Anthem itu menjadi lagu pengiring untuk promosi periklanan di media audio-visual elektronik (televisi, radio, internet).

Pola ini pun bisa diterapkan dalam pastoral kaum muda tingkat paroki atau keuskupan. Dengan cara ini, kreativitas dan keterlibatan kaum muda dibina. Anthem-anthem ini di kemudian hari boleh direkam untuk dijual kepada umat, termasuk kaum muda itu sendiri.

\section{Katekese}

Katekese termasuk bagian integral dalam HKMS. Katekese itu diberikan kepada kaum muda oleh uskup dari negara mereka. Misalnya, katekese bagi kaum muda Indonesia diberikan oleh uskup Indonesia. Salah satu tujuan dari pola ini adalah adanya kesempatan kaum muda bertemu secara langsung dengan uskup-uskup Indonesia dari keuskupan-keuskupan yang ada di Indonesia. Selain itu, katekese tentu saja meningkatkan pemahaman kaum muda tentang iman Katolik. Mengetahui dan memahami iman Katolik yang benar akan membantu penghayatan iman itu. Tantangan di sini adalah metode berkatekese yang mengena bagi kaum muda. ${ }^{40}$

Katekese semestinya mendapat perhatian serius dalam pertemuan-pertemuan kaum muda entah itu tingkat paroki atau keuskupan. Dalam katekese ini kaum muda dibagi ke dalam kelompokkelompok kecil. Sedangkan, untuk materi katekese bisa disamakan. Para pemberi materi dapat dipercayakan kepada para imam, biarawanbiarawati dan katekis. Sementara itu, waktu untuk uskup dialokasikan

${ }^{40}$ Tim Darke, Young and Catholic ..., hlm. 110; bdk. James J. Bacik, Spirituality In Transition ..., hlm. 79-82. 
khusus dalam suatu pertemuan secara menyeluruh dengan orang-orang muda untuk berkatekese dan berdialog secara terbuka. Dengan memberi porsi yang baik untuk katekese, kegiatan-kegiatan lain seperti olah raga, yang menurut observasi penulis cukup banyak memakan waktu, bisa dikurangi. ${ }^{41}$

\section{Sakramen Rekonsiliasi}

HKMS tak pernah ada tanpa sakramen rekonsiliasi. Panitia penyelenggara telah mengalokasikan waktu yang memadai untuk sakramen rekonsiliasi dengan melibatkan imam, uskup, dan Paus. Sakramen rekonsiliasi adalah perwujudan nyata dari panggilan setiap umat beriman kepada kesucian.

Menurut observasi penulis, sakramen rekonsiliasi hampir tak pernah menjadi salah satu agenda pertemuan kaum muda. Sementara kesempatan umat, termasuk kaum muda untuk bertemu dengan imam, sangatlah jarang. Kendatipun kesempatan itu memadai, peluang itu tidak digunakan untuk sakramen rekonsiliasi. Imam pun tampaknya kurang promotif dalam mengingatkan kaum muda akan makna sakramen rekonsiliasi. Padahal salah satu di antara Hukum Gereja adalah mengaku dosa sekurang-kurangnya sekali setahun.

Sakramen rekonsiliasi sudah semestinya mendapat perhatian dalam pertemuan-pertemuan kaum muda tingkat paroki dan keuskupan. Orang yang pertama memberi perhatian terhadap sakramen rekonsiliasi ini adalah pastor paroki.

\section{Kesimpulan}

HKMS telah terselenggara 29 kali antara kaum muda dengan Paus dengan agenda yang meliputi: prosesi dengan membawa Salib Tahun Penebusan dan ikon Bunda Maria, adorasi, katekese, sakramen reskonsiliasi dan misa penutupan. HKMS membutuhkan banyak biaya dan orang-orang yang berkehendak baik dan sukarela. Host families turut memberi nuansa tersendiri yang membuat HKMS semakin berkesan dan bermakna.

HKMS tidak terlepas dari protes dan kritik berkaitan dengan biaya dan sikap Gereja Katolik terhadap isu-isu tertentu seperti alat kontrasepsi dan perkawinan sejenis. Menghadapi protes dan kritik itu, kaum muda yang terlibat dalam HKMS menunjukkan perilaku baik dengan tidak bertindak kasar dan arogan. Mereka menahan diri bahkan

${ }^{41}$ James J. Bacik, Spirituality In Transition ..., hlm. 75. 
berdoa di tengah-tengah orang-orang yang menghina dan mencemoohkan mereka. Apakah ini salah satu efek dari HKMS? Jawaban atas pertanyaan ini masih perlu diteliti. Namun demikian, HKMS tidaklah tanpa efek. Efeknya cukup positif dan variatif sebagaimana telah disajikan di atas.

Dari seluruh uraian menyangkut HKMS, beberapa pokok diangkat sebagai rekomendasi untuk pastoral kaum muda. Sebagai rekomendasi, ia membutuhkan aplikasi yang pada gilirannya akan memberi bukti apakah rekomendasi itu signifikan dan relevan.

$$
====0000====
$$




\section{DAFTAR PUSTAKA}

BACIK, James J. Spirituality in Transition. Kansas City: Sheed \& Ward, 1996.

DIEZ, I Bosch, M. "A Jewish Reaction to WYD" dalam http://www.zenit.org/article-33294?1=english

DZIWISZ, S. Lebih Jauh bersama Karol Wojtyla: A Life with Karol. Malang: Dioma, 2010.

HOWELL, R. "4 Reasons to Go to World Youth Day" dalam http://www.ncregister.com/ daily-news/4-reasons-to-go-toworld-youth-day/

PONOMBAN, Terry Th. In Loving Memory of John Paul II. Yogyakarta: Yayasan Pustaka Nusantama, 2005.

THOMAS, M. dan GANADI, A. "Salib Pembawa Kabar" dalam Hidup, 43/66, hlm. 10-11.

WOODEN, C. “WYD and Vocations: Youth Want to Be Heard, Invited, Challenged" dalam http://www.catholicnews.com/data/stories/cns/1103210.htm 